\author{
І.М. ТОДУРОВ, О.В. ПЕРЕХРЕСТЕНКО, О.О. КАЛАШНІКОВ, С.В. КОСЮХНО, \\ В.М. ЯКИМЕЦЬ, О.І. ПЛЕГУЦА, О.А. ПОТАПОВ
}

\title{
СТАН КОМОРБДНОЇ ПАТОЛОГІЇ У ХВОРИХ НА МОРБІДНЕ ОЖИРІнНЯ
}

\author{
ДНУ «Центр інноваційних медичних технологій НАН України», м. Київ, Україна
}

\begin{abstract}
Мета: покращити результати лікування хворих на морбідне ожиріння шляхом оцінки частоти розвитку та особливостей супутньої патології.

Матеріали і методи. Проаналізовано результати передопераційного клініко-лабораторного та інструментального обстеження 205 хворих на морбідне ожиріння.

Результати. Супутні захворювання діагностовано у 203 (99 \%) хворих на морбідне ожиріння, включених у дослідження. В структурі супутньої патології переважали захворювання серцево-судинної системи у 135 (65,8 \%) хворих, порушення вуглеводного - в 135 (65,8 \%) пацієнтів та ліпідного обміну - в 161 (78,5 \%) хворого, що віддзеркалюють патогенетичну сутність метаболічного синдрому та суттєво підвищують ризик передчасної смерті. Захворювання дихальної системи діагностовано у 63 (30,7 \%) хворих, системи травлення - у 130 (63,4 \%) пацієнтів.

Висновки. Характерною особливістю хворих на морбідне ожиріння є висока частота, системність та, в більшості випадків, мультифокальність органних уражень, що вимагає системної реалізації мультидисциплінарного підходу для покращення результатів лікування означеної категорії пацієнтів.
\end{abstract}

\section{КЛЮчОВІ СЛОВА: морбідне ожиріння; коморбідна патологія.}

Згідно з прогнозами фрахівців ВООЗ очікується, що XXI століття стане періодом неінфекційних епідемій та пандемій. При цьому одне 3 перших місць в переліку потенційних глобальних загроз для здоров'я та життя сучасного людства зайняло ожиріння. У 2016 р. кількість дорослих людей 3 надмірною масою тіла перевищила цифру 1,9 млрд (39 \% жителів нашої планети віком понад 18 років), з них більш ніж 650 млн (13\%) осіб страждали від ожиріння [1]. Результати численних клініко-експериментальних досліджень переконливо довели, що надмірне накопичення жирової тканини є першопричиною розвитку тяжких супутніх захворювань фрактично всіх органів та систем людського організму включно із серйозними психосоціальними проблемами [2].

Одна із причин глобалізації загрози ожиріння пов'язана, 3-поміж іншого, і з його економічними наслідками. При цьому загальна вартість ожиріння складається із прямих та непрямих фрінансових витрат. Прямі видатки включають затрати на профрілактику, діагностику та лікування ожиріння та пов'язаних із ним супутніх захворювань. Уже сьогодні в Європейському регіоні ВООЗ на лікування проблем, пов'язаних із ожирінням у дорослих, витрачають 6 \% коштів, спрямованих на охорону здоров'я [6]. Але основну та значно більшу частину фрінансового навантаження складають непрямі витрати. Вони пов'язані зі зниженням економічного рівня суспільства через зменшення перспектив працевлаштування, збільшення числа та тривалості випадків тимчасової непрацездатності, стійку непрацездатність багатьох хворих, високі показники передчасної смертності серед цієї категорії пацієнтів. Непрямі видатки нині доповнились витратами на створення спеціальних місць для таких осіб у громадських місцях, транспорті, лікарнях [3, 4].

Проте, незважаючи на колосальні зусилля, жодній країні світу дотепер не вдалося взяти цю пандемію під контроль. Тому не дивно, що останнім часом в англомовній літературі з'явився новий термін «globesity» (скорочення від «global obesity») - глобальне ожиріння [7].

При цьому жодна 3 відомих консервативних програм корекції надмірної маси тіла, що включають дієтотерапію, оптимізацію режиму фрізичної активності, поведінкову терапію та медикаментозне лікування, фрактично не демонструють достатньої клінічної ефективності навіть у хворих зі

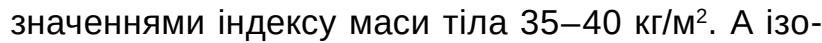
льоване застосування консервативних методик лікування у хворих із морбідним ожирінням взагалі вважається фрактично безперспективним [8, 9]. На сьогодні загальновизнано, що єдиним реальним методом ефективної медичної допомоги таким хворим є баріатрична хірургія $[2,5]$.

3 огляду на вищезазначене вивчення частоти розвитку та особливостей супутньої патології у хворих на морбідне ожиріння є безумовно 
актуальним. Адже така об'єктивна оцінка стану здоров'я означеної категорії пацієнтів дозволить оптимізувати підходи до лікування ожиріння, зокрема визначитись щодо доцільності формування спеціалізованих мультидисциплінарних команд.

Мета роботи: покращити результати хірургічного лікування хворих на морбідне ожиріння шляхом оцінки частоти розвитку та особливостей супутньої патології.

Матеріали і методи. Дослідження проведено на основі результатів обстеження 205 хворих на морбідне ожиріння (87 чоловіків та 118 жінок віком від 18 до 68 років) у ДУ «Національний інститут хірургії та трансплантології імені О. О. Шалімова НАМН України» на етапі підготовки до баріатричних оперативних втручань. Всіх пацієнтів було включено в дослідження за умови отримання від них добровільної інформованої згоди.

Хворим проводили комплекс первинних клініколабораторних та інструментальних обстежень за стандартними методиками, що були спрямовані на діагностику супутніх захворювань, асоційованих $з$ ожирінням, передусім - маркерів метаболічного синдрому. До переліку обов'язкових лабораторних досліджень включали загальний аналіз крові, загальний аналіз сечі, біохімічний аналіз крові, ліпідограму, коагулограму, ревмопроби. Пероральний тест толерантності до глюкози проводили згідно з рекомендаціями ВООЗ. У хворих із порушеннями вуглеводного обміну визначали рівень глікозильованого гемоглобіну (HbA1c), інсуліну, С-пептиду, лептину, проводили розрахунок індексу інсулінорезистентності HOMA-IR. Стандартний комплекс інструментальних обстежень включав електрокардіографію, ультразвукове дослідження серця та глибоких вен нижніх кінцівок, оглядову рентгенографрію органів грудної порожнини, спірометрію, ультразвукове обстеження органів черевної порожнини та заочеревинного простору, езофагогастродуоденофіброскопію, рН-метрію стравоходу та шлунка. Пацієнти проходили консультації суміжних спеціалістів - ендокринолога, кардіолога, судинного хірурга, гастроентеролога, фахівця 3 лікувальної фрізкультури, психолога, дієтолога. Якість життя пацієнтів досліджено за методикою Moorehead-Ardelt II шляхом серійного анкетування. Діагноз метаболічного синдрому в хворих, включених у дослідження, встановлювали згідно з критеріями ВООЗ (1999).

Статистичну обробку даних проведено з використанням методів варіаційної та описової статистики за допомогою пакета статистичного аналізу Statistica 6.0. Розбіжності отриманих результатів вважали статистично значимими при p<0,05, що забезпечує 95 \% рівень ймовірності.

Результати дослідження та їх обговорення. Середній вік хворих, включених у дослідження, -
$(42,9 \pm 10,2)$ року. Тривалість ожиріння до моменту звернення за хірургічною допомогою склала від 4 до 30 років (в середньому - $(13,2 \pm 7,8)$ року).

Середня маса тіла пацієнтів, включених у дослідження, становила $(154,3 \pm 32,4)$ кг (від 100 до 270 кг), із середнім значенням надлишку маси тіла $(87,4 \pm 27,3)$ кг (від 46 до 163 кг). Індекс маси тіла пацієнтів, включених у дослідження, пере-

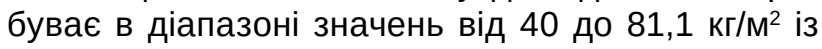
середнім значенням показника $(51,7 \pm 8,4)$ кг/м². Частоту та структуру супутніх захворювань в означених хворих наведено у таблиці 1.

Вищенаведені дані засвідчили вкрай високу частоту розвитку супутньої патології у хворих на морбідне ожиріння (відсутність супутніх захворювань констатовано лише у 2 (1 \%) пацієнтів молодого віку), системність та, в більшості випадків, мультифокальність органних уражень.

У структурі супутніх захворювань пацієнтів, які були включені в дослідження, переважала патологія серцево-судинної системи в 135 (65,8 \%) хворих, порушення вуглеводного - у 135 (65,8 \%) пацієнтів та ліпідного обміну - в 161 (78,5 \%) хворого, що $€$ основними маркерами метаболічного синдрому. Захворювання дихальної системи діагностовано у 63 (30,7 \%) хворих та системи травлення - у 130 (63,4 \%) пацієнтів. Діагноз метаболічного синдрому встановлено у 135 (65,8 \%) хворих, включених у дослідження. Про тяжкість перебігу супутніх захворювань свідчить той фракт, що у 102 (49,7 \%) хворих, включених у дослідження, констатовано стійку втрату працездатності (інвалідність 2 та 3 груп) у зв'язку з патологією, пов'язаною із ожирінням. При цьому, при оформленні інвалідності, ожиріння як основний діагноз не встановлено у жодного з пацієнтів (воно, іноді, фрігурувало лише як супутнє захворювання).

Тривалість консервативного лікування ожиріння та супутніх захворювань у всіх хворих, включених у дослідження, становила від 3 до 15 років. Проте консервативні програми корекції надмірної маси тіла попри їх комплексність та тривалість не продемонстрували достатньої та стійкої клінічної еорективності. У більшості хворих короткочасне зменшення надмірної маси тіла перебувало в діапазоні значень 3-7 \% з наступною рецидивною прибавкою ваги протягом 8-26 місяців після завершення основної програми лікування. Така динаміка маси тіла вочевидь не дозволила досягти адекватного контролю супутніх захворювань, асоційованих з ожирінням.

Варто зауважити, що морбідне ожиріння та пов'язані з ним супутні захворювання стали причиною критично низької якості життя пацієнтів із середніми значеннями індексу якості життя за Moorehead-Ardelt II $(-1,6 \pm 0,6)$ бала. Якісна оцінка числового рівня вищеозначеного показника перебувала у діапазоні значень «дуже погано» та 
Таблиця 1. Супутні захворювання у пацієнтів на морбідне ожиріння до виконання баріатричного оперативного втручання

\begin{tabular}{|c|c|c|}
\hline Супутнє захворювання & Абсолютна кількість, $\mathrm{n}$ & Частота, \% \\
\hline Артеріальна гіпертензія & 135 & 65,8 \\
\hline Ішемічна хвороба серця & 42 & 20,5 \\
\hline Цукровий діабет 2 типу & 59 & 28,8 \\
\hline Порушення толерантності до глюкози & 74 & 36,1 \\
\hline Дисліпідемія & 161 & 78,5 \\
\hline Хронічна лімфровенозна недостатність нижніх кінцівок & 45 & 22,0 \\
\hline Синдром сонного апное & 25 & 12,2 \\
\hline Бронхіальна астма/Хронічні обструктивні захворювання легень & 38 & 18,5 \\
\hline Жовчнокам'яна хвороба & 40 & 19,5 \\
\hline Гастроезофагеальна рефлюксна хвороба & 75 & 36,5 \\
\hline Хронічна виразкова хвороба дванадцятипалої кишки & 18 & 8,7 \\
\hline Хронічний ерозивний гастродуоденіт & 42 & 20,5 \\
\hline Грижа передньої черевної стінки & 19 & 9,3 \\
\hline Репродуктивна дисорункція & 30 & 14,6 \\
\hline Захворювання опорно-рухового апарату & 37 & 18,0 \\
\hline Стресове нетримання сечі & 13 & 6,3 \\
\hline Інша патологія & 10 & 4,9 \\
\hline Загальна кількість хворих із супутніми захворюваннями* & 203 & 99,0 \\
\hline
\end{tabular}

Примітка: * у одного пацієнта могло бути одне чи декілька супутніх захворювань.

«погано» у 174 (84,8 \%) хворих, включених у дослідження. При цьому в жодного з пацієнтів бальна оцінка індексу якості життя в передопераційному періоді не досягла рівня «добре».

Дані, отримані в процесі дослідження (з урахуванням світового досвіду), дозволяють стверджувати, що морбідне ожиріння, з точки зору сучасної медицини, є мультидисциплінарною проблемою. Адже широкий спектр і тяжкість асоційованих із ним супутніх захворювань та метаболічних порушень диктують необхідність залучення до діагностично-лікувального процесу фрахівців різних профрілів, об'єднаних у спеціалізовані команди. Саме такий підхід дозволяє оптимізувати стратегію лікування кожного конкретного хворого з урахуванням його індивідуальних особливостей. 3 огляду на низьку ефективність консервативних програм лікування морбідного ожиріння та супутніх захворювань, пов'язаних із ним, доцільне більш широке впровадження баріатричної хірургії в Україні. При цьому робота багатопрофрільних команд має базуватись на чіткому розумінні причинно-наслідкового зв'язку між надмірним накопиченням жирової тканини в організмі та розвитком супутньої патології. Усвідомлення цього беззаперечного фракту сприятиме суттєвому підвищенню ефрективності лікування за рахунок концентрації зусиль лікарів не на малоперспективній терапії множинних розладів здоров'я, а на зниженні зайвої маси тіла, що, в свою чергу, дозволить компенсувати і асоційовані з ожирінням захворювання.

\section{Висновки}

Характерною особливістю хворих на морбідне ожиріння $€$ висока частота, системність та, в більшості випадків, мультифокальність органних уражень, що вимагає системної реалізації мультидисциплінарного підходу для покращення результатів лікування означеної категорії пацієнтів.

Перспективи подальших досліджень. Вивчення можливостей та перспективи використання міні-інвазивних баріатричних операцій у хворих із морбідним ожирінням потребують проведення рандомізованих мультицентрових клінічних досліджень.

\section{Список літератури}

1. Ожиріння - неінфекційна пандемія в світі [Електронний ресурс]. - Режим доступу : http://www.who.int/gho/ncd/ risk_factors/overweight/en/ - Назва з екрана.

2. Bariatric surgery in class I obesity: A position statementfrom the International Federation for the Surgery of Obesity and Metabolic Disorders (IFSO) / L. Busetto, J. Dixon, M. de Luca [et al.] // Obes. Surg. - 2014 - Vol. 24. - P. 487-519.

3. Economic costs of overweight and obesity / T. Lehnert, D. Sonntag, A. Konnopka [et al.] // Best Pract. Res. Clin. Endocrinol. Metab. - 2013 - Vol. 27 (2). - P. 105-115.

4. Global, regional, and national prevalence of overweight and obesity in children and adults during 1980-2013: a systematic analysis for the Global Burden of Disease Study 2013 / M. Ng, T. Fleming, M. Robinson [et al.] // Lancet. 2014. - Vol. 384. - P. 766-781. 
5. Kang J. H. Effectiveness of bariatric surgical procedures: A systematic review and network meta-analysis of randomized controlled trials / J. H. Kang, Q. A. Le // Medicine. - 2017. - Vol. 96 (46). - P. e8632.

6. Rubio M. A. Pharmacological treatment of obesity in Europe: waiting for the arrival of the white blackbird / M. A. Rubio // Endocrinol. Nutr. - 2014. - Vol. 61 (10). - P. 501-514.

7. Seidell J. C. The global burden of obesity and the challenges of prevention / J. C. Seidell, J. Halberstadt // Ann. Nutr. Metab. - 2015 - Vol. 66, Suppl. 2. - P. 7-12.

8. Update on pharmacology of obesity: Benefits and risks / L. Cabrerizo-Garcha, A. Ramos-Levn, C. Moreno-Lopera, M. A. RubioHerrera // Nutr. Hosp. - 2013. - Vol. 28, Suppl. 5. - P. 121-127.

9. Yanovski S. Z. Long-term drug treatment for obesity: A systematic and clinical review / S. Z. Yanovski, J. A. Yanovski // JAMA. - 2014. - Vol. 311. - P. 74-86.

\section{References}

1. Ozhyrinnia - neinfektsiina pandemiia v sviti [Obesity - non-infectious pandemia in the world]. [Elektronnyi resurs]. Retrieved from: http://www.who.int/gho/ncd/risk_factors/overweight/en/ - Nazva z ekranu.

2. Busetto, L., Dixon, J., \& de Luca, M. (2014). Bariatric surgery in class I obesity: A position statementfrom the International Federation for the Surgery of Obesity and Metabolic Disorders (IFSO) Obes. Surg., 24, 487-519.

3. Lehnert, T., Sonntag, D., \& Konnopka, A. (2013). Economic costs of overweight and obesity. Best Pract. Res. Clin. Endocrinol. Metab., 27 (2), 105-115.

4. Ng, M., Fleming, T., \& Robinson, M. (2014). Global, regional, and national prevalence of overweight and obesity in children and adults during 1980-2013: a systematic analysis for the Global Burden of Disease Study 2013. Lancet, 384, 766-781.

5. Kang, J.H. \& Le, Q.A. (2017). Effectiveness of bariatric surgical procedures: A systematic review and network metaanalysis of randomized controlled trials. Medicine, 96 (46), 8632.

6. Rubio, M.A. (2014). Pharmacological treatment of obesity in Europe: waiting for the arrival of the white blackbird. Endocrinol. Nutr., 61 (10), 501-514.

7. Seidell, J.C. \& Halberstadt J. (2015). The global burden of obesity and the challenges of prevention. Ann. Nutr. Metab., 66 (2), 7-12.

8. Cabrerizo-Garcna, L., Ramos-Levn, A., Moreno-Lopera, C., \& RubioHerrera, M.A. (2013). Update on pharmacology of obesity: Benefits and risks. Nutr. Hosp., 28 (5), 121-127.

9. Yanovski, S.Z. \& Yanovski, J.A. (2014). Long-term drug treatment for obesity: A systematic and clinical review. JAMA, 311, 74-86.

\section{СОСТОЯНИЕ КОМОРБИДНОЙ ПАТОЛОГИИ У БОЛЬНЫХ С МОРБИДНЫМ ОЖИРЕНИЕМ}

И.М. Тодуров, А.В. Перехрестенко, А.А. Калашников, С.В. Косюхно, В.Н. Якимец, А.И. Плегуца, А.А. Потапов ГНУ «Центр инновационных медицинских технологий НАН Украины», г. Киев, Украина

Цель: улучшить результаты лечения больных с морбидным ожирением путем оценки частоты развития и особенностей сопутствующей патологии.

Материалы и методы. Проанализированы результаты предоперационного клинико-лабораторного и инструментального обследования 205 больных с морбидным ожирением.

Результаты. Сопутствующие заболевания диагностированы у 203 (99 \%) больных с морбидным ожирением, включенных в исследование. В структуре сопутствующей патологии преобладали заболевания сердечно-сосудистой системы у 135 (65,8 \%) больных, нарушения углеводного - в 135 (65,8 \%) пациентов и липидного обмена - у 161 (78,5 \%) больного, отражающие патогенетическую сущность метаболического синдрома и существенно повышающие риск преждевременной смерти. Заболевания дыхательной системы диагностированы у 63 (30,7 \%) больных, системы пищеварения - у 130 (63,4 \%) пациентов.

Выводы. Характерной особенностью больных с морбидным ожирением является высокая частота, системность и, в большинстве случаев, мультифокальность органных поражений, что требует системной реализации мультидисциплинарного подхода для улучшения результатов лечения указанной категории пациентов.

КЛЮЧЕВЫЕ СЛОВА: морбидное ожирение; коморбидная патология.

\section{THE STATE OF COMORBID PATHOLOGY IN PATIENTS WITH MORBID OBESITY}

I.M. Todurov, O.V. Perekhrestenko, O.O. Kalashnikov, S.V. Kosyukhno, V.M. Yakimets, O.I. Plehutsa, O.A. Potapov Center for Innovative Medical Technologies of NAS of Ukraine, Kyiv, Ukraine

Purpose: to improve the results of treatment of morbidly obese patients by assessing frequency and characteristics of comorbidity.

Materials and Methods. The results of a preoperative clinical, laboratory, instrumental examination of 205 patients with morbid obesity were analyzed.

Results. Concomitant diseases were diagnosed in 203 (99\%) morbidly obese patients included in the study. In the structure of concomitant pathology cardiovascular diseases prevailed - $135(65.8 \%)$ patients, carbohydrate 
metabolism disorders - 135 (65.8\%) patients and lipid metabolism disorders - 161 (78.5\%) patients, reflecting the pathogenesis of the metabolic syndrome and significantly increasing the risk of premature death. Diseases of the respiratory system were diagnosed in 63 (30.7\%) patients and digestive system - in $130(63.4 \%)$ patients.

Conclusions. Peculiarities of morbidly obese patients are high frequency, systemic and, in the most cases, multifocality of organ lesions that requires a systemic implementation of a multidisciplinary approach to improve the results of treatment of this category of patients.

KEY WORDS: morbid obesity; comorbid pathology.

Рукопис надійшов до редакції 12.07.2018 p.

Відомості про авторів:

Тодуров Іван Михайлович - доктор медичних наук, професор, директор ДНУ «Центр інноваційних медичних технологій НАН України», лауреат Державної премії України; тел.: +38(044) 272-22-66.

Перехрестенко Олександр Васильович - кандидат медичних наук, заступник директора з наукової роботи ДНУ «Центр інноваційних медичних технологій НАН України», провідний науковий співробітник відділу ендокринної та метаболічної хірургії; тел.: +38(097) 759-22-44.

Калашніков Олександр Олександрович - кандидат медичних наук, провідний науковий співробітник відділу малоінвазивної хірургії ДНУ «Центр інноваційних медичних технологій НАН України»; тел.: +38(050) 334-68-30; +38(044) 272-22-66.

Косюхно Сергій Вікторович - кандидат медичних наук, завідувач відділу малоінвазивної хірургії ДНУ «Центр інноваційних медичних технологій НАН України; тел.: +38(044) 272-22-66.

Якимець Володимир Миколайович - доктор медичних наук, професор, заступник директора з науково-організаційної роботи ДНУ «Центр інноваційних медичних технологій НАН України»; тел.: +38(044) 272-22-66.

Плегуца Олександр Іларійович - старший науковий співробітник відділу ендокринної та метаболічної хірургії ДНУ «Центр інноваційних медичних технологій НАН України»; тел.: +38(044) 272-22-66; +38(093) 763-97-43.

Потапов Олексій Андрійович - учений секретар, науковий співробітник відділу малоінвазивної хірургії ДНУ «Центр інноваційних медичних технологій НАН України»; тел.: +38(044) 272-22-66. 